\title{
Impact of fibre incorporation and compaction method on properties of pervious concrete
}

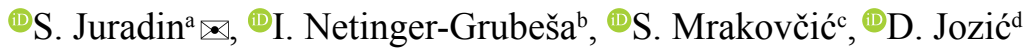 \\ a. Faculty of Civil Engineering, Architecture and Geodesy, University of Split, (Split, Croatia)
b. Faculty of Civil Engineering and Architecture Osijek, Josip Juraj Strossmayer University of Osijek, (Osijek, Croatia) \\ c. Faculty of Civil Engineering, University of Rijeka, (Rijeka, Croatia) \\ d. Faculty of Chemistry and Technology, University of Split, (Split, Croatia) \\ sandra.juradin@gradst.hr
}

Received 22 June 2020

Accepted 1 December 2020

Available on line 04 June 2021

\begin{abstract}
This paper deals with the possibility of the improvement of pervious concrete properties by incorporation of different types of fibres and studies the effect of short duration vibration of pervious concrete properties in comparison with compaction with wooden lath and hammer. Ten mixtures of pervious concrete were prepared, five of which were compacted with wooden lath and hammer and five by short duration vibration. Density, porosity, permeability and mechanical properties were tested for in hardened pervious concrete specimens. It was concluded that mixtures compacted by short duration vibration had better mechanical properties due to the formation of a viscous layer at the contact surface between the aggregate grain and the cement matrix during the compaction, as well as pore-related properties. The addition of fibres negatively affected porosity and permeability but generally improved mechanical properties of concrete. The positive effect of fibre addition was more emphasised in cases of vibrated mixtures.
\end{abstract}

KEY WORDS: Concrete; Permeability; Mechanical properties; Vibration; Fibre reinforcement.

Citation/Citar como: Juradin, S.; Netinger-Grubeša, I.; Mrakovčić, S.; Jozić, D. (2021) Impact of fibre incorporation and compaction method on properties of pervious concrete. Mater. Construcc. 71 [342], e245. https://doi.org/10.3989/mc.2021.08020.

RESUMEN: Impacto de la incorporación de fibras y del método de compactación en las propiedades de hormigones porosos. Este artículo trata sobre la posibilidad de mejorar las propiedades de hormigones porosos mediante la incorporación de distintos tipos de fibras, así como del estudio del efecto de vibraciones de corta duración en dichas propiedades en comparación con el método de compactación realizado con listón de madera y mazo. Se prepararon diez mezclas de hormigón, cinco de ellas compactadas con listón de madera y mazo, y 5 con vibración de corta duración. Se midió la densidad, porosidad, permeabilidad y propiedades mecánicas de los hormigones endurecidos. Se concluyó que las mezclas compactadas mediante vibración de corta duración mostraron mejores propiedades mecánicas debido a la formación de una capa viscosa en la superficie de contacto entre el árido y la matriz cementante durante el proceso de compactación, así como a las propiedades porosas resultantes. La adición de fibras afectaba negativamente a la porosidad y la permeabilidad de las mezclas, pero mejoraba las propiedades mecánicas. El efecto positivo de la adición de fibras era más evidente en las mezclas compactadas mediante vibración.

PALABRAS CLAVE: Hormigón; Permeabilidad; Propiedades mecánicas; Vibración; Refuerzo de fibras.

Copyright: (C2021 CSIC. This is an open-access article distributed under the terms of the Creative Commons Attribution 4.0 International (CC BY 4.0) License. 


\section{INTRODUCTION}

The components from which the pervious concrete is made correspond to those of normal concrete with a difference in the grain size gradation where, only one coarse grain fraction or two non-adjacent fractions are used to achieve a porosity of 11 to $35 \%$ (1-3). In addition, the fine aggregate is omitted completely or added in a very small percentage, so that it is known as no-fines concrete (4). Pervious concrete is characterized by its ability to drain water through the concrete mass (5), its high noise absorption and its lighter color, which has a positive effect on reducing the occurrence of heat islands in urban areas (6). Pervious concrete also has some disadvantages, namely poor abrasion resistance, poor resistance to freezing and thawing cycles and relatively low strength (7). The compressive strength of permeable concrete can be up to 30 $\mathrm{MPa}$ (5), and the bending tensile strength up to 3.5 MPa (3). Micro-reinforcement of concrete with steel, polymer or glass fibers can improve its properties, in particular its shrinkage, abrasion and impact resistivity and flexural strength (8-10). Since water permeability/ drainage is the main purpose of pervious concrete, steel fibres, which are known for their tendency to corrode, would not be a good choice for incorporation in such concrete. Finally, due to their inflexibility, steel fibres could negatively affect the pore connectivity in pervious concrete and consequently its drainage capacity.

In accordance with the above, glass, carbon, synthetic and cellulose fibres can be added to improve the weaker properties of permeable concrete $(3,11$, 12). After (12-14), the volume fraction of microfibres in pervious concrete, with which satisfactory properties are achieved, is between 0.07 and $0.2 \%$. Kevern et al. (12) concluded that the addition of macrosynthetic fibres in pervious concrete reduces its permeability and infiltration coefficient, but, as in (15), does not have a significant effect on the results of compressive and tensile strength.

In contrast, Rangelov et al. (6) used carbon fibres to reinforce permeable concrete and achieved an increase in the strength properties of the concrete, and Liu et al. (16), who increased the flexural tensile strength with basalt fibre reinforcement. Amde and Rogge (11) investigated permeable concrete with various additives, including cellulose fibres, which have been shown to effectively improve the tensile strength and resistance of the concrete to abrasion and freeze-thaw cycles.

Since permeable concrete has poor workability, it must be adequately compacted to achieve satisfactory mechanical properties while maintaining the required degree of porosity (3). Numerous studies of compaction methods have been carried out in the laboratory to obtain samples identical to those produced in-situ. Shu et al. (17) applied compaction under laboratory conditions using a tamping rod to prepare permeable concrete samples. To consolidate the samples, in $(1,18)$ compaction with a tamping rod and Proctor hammer was used, in (1) also compaction by dropping the mold from a certain height and in (19) the centrifugal compactor was used as the compaction method. Putman and Neptune (1) concluded that compaction with a Proctor hammer best simulates the compaction method on a construction site.

Although most researchers use a ram rod as the compaction method, samples of permeable concrete compacted in this way achieve an increased degree of variability in their properties, which is caused by the creation of rod holes (1). Li et al. (20) used a metal roller in the laboratory to compact permeable concrete. Zhuge (21) used two different compaction methods: a standard compaction method and a vibratory compaction method.

By vibrating, they increased the adhesion between the aggregate grains and the cement matrix without significantly reducing the permeability of the concrete. Yang et al. (4) also compacted permeable concrete on a vibrating table and the vibration process lasted $40 \mathrm{~s}$ for each sample. Juradin et al. (22) compacted the samples on a vibrating table. In three series of samples, the first two layers were vibrated for 5 seconds and the third for 30 seconds (the total vibration time was $40 \mathrm{~s}$ ), while in four series of samples, three layers were vibrated evenly for three times each, so that the total vibration time was less than $12 \mathrm{~s}$. The authors concluded that vibration favourably affects the permeability and strength of concrete, longer vibration gives better permeability and shorter vibration gives better strength.

Due to its lower strength, the application of pervious concrete is focused on construction of parking lots, pathways and lightweight traffic roads. Enhanced porosity, which influences structural and functional properties of pervious concrete (23), leads to applications where the acoustic absorption or storm water runoff control is needed. To widen the application of this kind of concrete, researches are continuously working on the development of porous concrete with enhanced properties such as high performance pervious concrete (24-26) or fibre reinforced pervious concrete (27-32). Zhong and Wille (33) analysed and discussed the influence of fibre reinforcement on the freeze-thaw durability of pervious concrete and concluded that the improvement can be achieved through the incorporation of fibres into high performance pervious concrete matrix. For pavement structures the flexural strength is a measure of the resistance to structural failure. As for the conventional concrete, the addition of fibres to pervious concrete can enhance its flexural strength. Oni et al. (32) investigated pervious concrete pavement bricks reinforced with kevlar, polyvinyl alcohol and ultra-high molecular weight polyethylene fibres and achieved $9.5 \%$ increase of flexural strength in comparison to control mix that shows the effectiveness of fibres for pavement applications which are regularly subjected to two dimensional flexural stress. AlShareedah et al. (34) investigated the potential of pervious concrete reinforced with fibres made of recycled cured carbon fibre composite material through a pervious concrete pavement demonstration project. The 
pavement sections with reinforcement had the same values of compressive and flexural strength as the control section, but higher infiltration rates and lower surface deflection. FORTA Technical Report (35) has carried out a number of project trials and applications of synthetic fibres in pervious concrete that led to the conclusion that longer fibre lengths and higher dosages are the best opportunity to increase pervious concrete toughness and durability. Novak et al. (36) investigated the mechanical properties of pervious recycled aggregate fibre reinforced concrete. The obtained findings showed that fibre reinforced pervious concrete has a very ductile behavior and a high post-cracking strength.

This paper deals with the possibility of the improvement of pervious concrete properties by incorporation of various types of fibres and studies the effect of short duration vibration on pervious concrete properties in comparison with incorporation by wooden lath and hammer.

\section{EXPERIMENTAL WORK}

\subsection{Materials and preparation of specimens}

In this study, ten mixtures of pervious concrete were prepared. Regarding the composition of mixtures, there were five different pervious concrete mixtures, each compacted using two different methods: (1) compaction with wooden lath and hammer and (2) vibration on vibrating table for $5 \mathrm{~s}$. The cement used in the preparation of specimens was CEM I 42.5 R; its powder X-ray diffraction (XRPD) pattern and its mineral composition are shown in Figure 1. Mineralogical composition of the CEM I 42.5 R was determined from the XRPD pattern and the quantity of each phase was determined using the Rietveld refinement method $(\mathrm{Rwp}=7.8)$. The fraction of the aggregate used for concrete mixture preparation

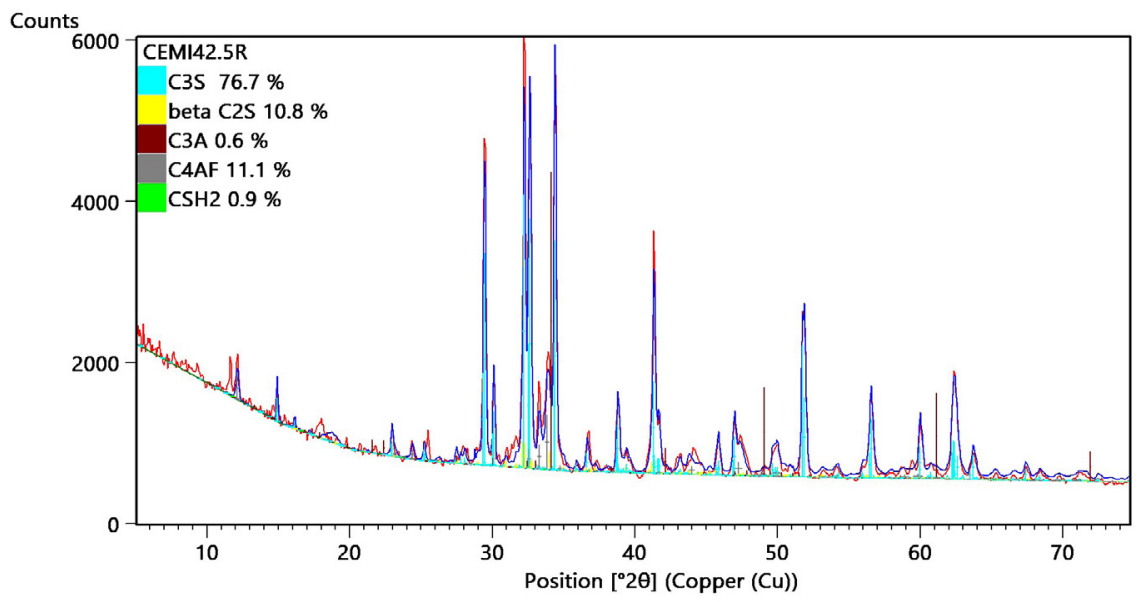

Figure 1. XRPD pattern of the cement CEM I 42.5 R.

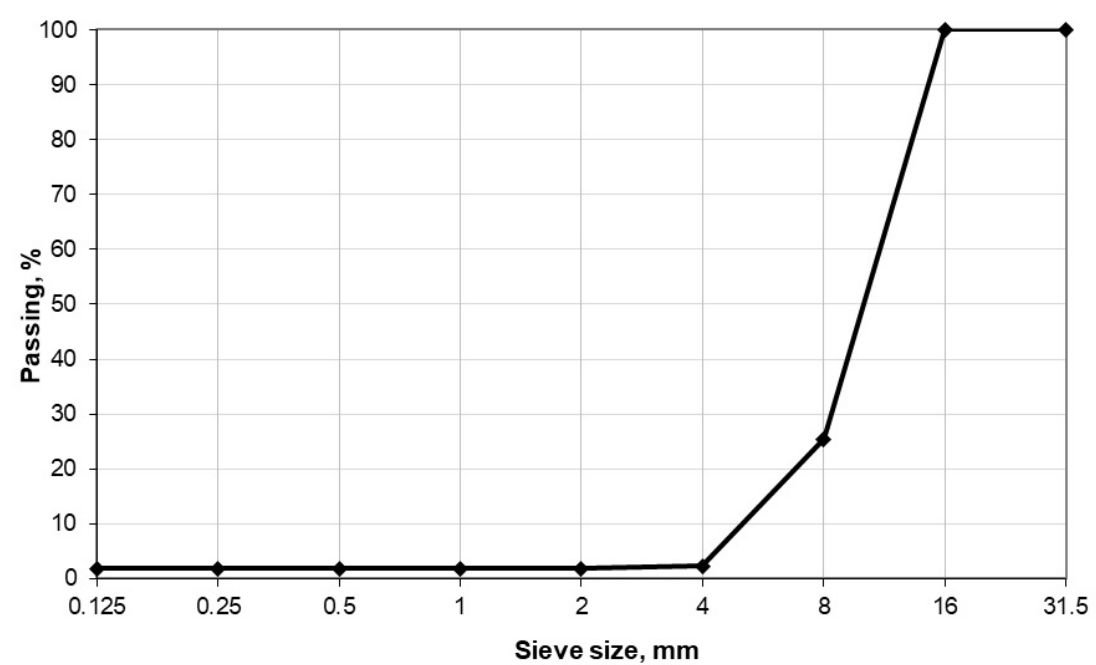

FIGURE 2. Grain-size distribution curve of aggregate fraction. 


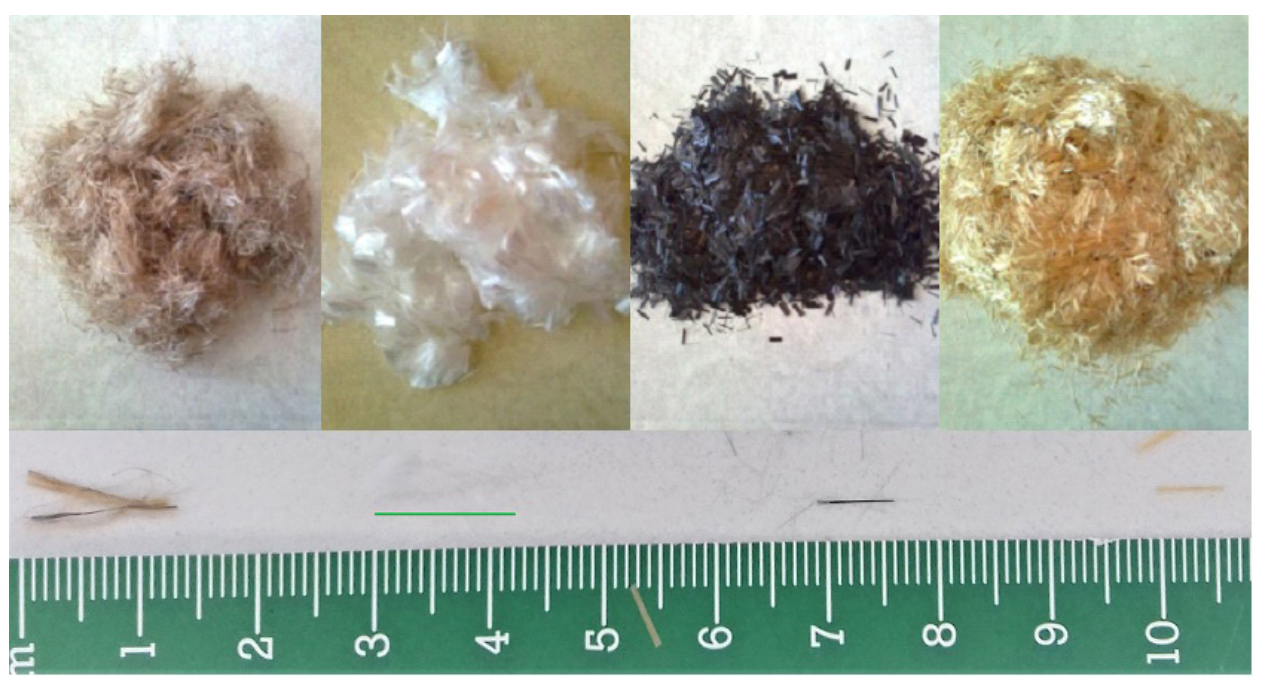

FigURE 3. The samples of hemp, polypropylene, carbon and glass fibres with the scale in $\mathrm{cm}$.

was $8-16 \mathrm{~mm}$, with a grain size distribution curve as shown in Figure 2.

The water-to-cement ratio was 0.35 and the amount of water was determined so that a stable ball of concrete could be formed in hand without crumbling (5). Four different types of fibres (Figure 3) glass $(\mathrm{G})$, polypropylene (PP), hemp $(\mathrm{H})$ and carbon (C) fibres - were added to the mixtures. All fibres were purchased at the market and the fibre lengths, diameter, tensile strength and densities are shown in Table 1. The hemp fibres, in their natural length of $1 \mathrm{~m}$, were treated in 5\% sodium hydroxide for one week, then washed in water, dried at room temperature, and manually cut to the length of $10 \pm 2 \mathrm{~mm}$. The amount of each sort of fibre was $0.18 \%$ of the total volume, which corresponds to the recommended amount in (12-14).

The composition of the mixtures is given in Table 1. To avoid a balling effect in mixtures, the fibres were added manually during mixing.
The pervious concrete mixture $\mathrm{E}$ had no fibres and it was compacted by 25 strokes with a wooden lath and hammer; this method was also used for G, C, PP, and $\mathrm{H}$. The designation of mixtures comes from the type of fibres contained in the specific mixture and the compaction method used; vibrated specimens contain the letter $\mathrm{V}$ in their designation.

\subsection{Testing of fresh and hardened concrete specimens}

The consistency of fresh concrete was determined according to (37) and the slump test values achieved were between 0 and $1 \mathrm{~cm}$, Figure 4 . Specimens were cast to moulds and compacted with a wooden lath and hammer or by vibration of $15 \mathrm{~cm}$-sized cubes and cylinders which were $10 \mathrm{~cm}$ in diameter and $20 \mathrm{~cm}$ in height. The specimens for testing of density, porosity and strength were extracted from the

TABLE 1. Mixture compositions for $1 \mathrm{~m}^{3}$ of pervious concrete.

\begin{tabular}{|c|c|c|c|c|c|c|c|c|c|}
\hline \multirow{2}{*}{ Mixture } & \multirow{2}{*}{$\begin{array}{c}\text { Cem } \\
\mathrm{kg}\end{array}$} & \multirow{2}{*}{$\mathbf{w} / \mathbf{c}$} & \multirow{2}{*}{$\begin{array}{c}\text { Aggregate } \\
8-16 \mathrm{~mm} \\
\mathrm{~kg}\end{array}$} & \multicolumn{6}{|c|}{ Fibre } \\
\hline & & & & type & $\begin{array}{c}\text { density } \mathbf{g} / \\
\mathbf{c m}^{3}\end{array}$ & $\begin{array}{c}\text { diameter } \\
\text { mm }\end{array}$ & $\begin{array}{c}\text { length } \\
\text { mm }\end{array}$ & $\begin{array}{c}\text { tensile strength } \\
\text { MPa }\end{array}$ & kg \\
\hline E, EV & 350 & 0.35 & 1481.5 & - & - & - & - & & - \\
\hline $\mathrm{G}, \mathrm{GV}$ & 350 & 0.35 & 1481.5 & glass & 2.5 & 15 & 6 & $1050-3850$ & 4.5 \\
\hline $\mathrm{C}, \mathrm{CV}$ & 350 & 0.35 & 1481.5 & carbon & 1.9 & $5-10$ & 6 & $1800-2600$ & 3.42 \\
\hline PP, PPV & 350 & 0.35 & 1481.5 & PP & 0.9 & $19.8-31$ & 12 & $560-770$ & 1.64 \\
\hline $\mathrm{H}, \mathrm{HV}$ & 350 & 0.35 & 1481.5 & hemp & 1.5 & $500-620$ & 10 & $400-938$ & 2.7 \\
\hline
\end{tabular}




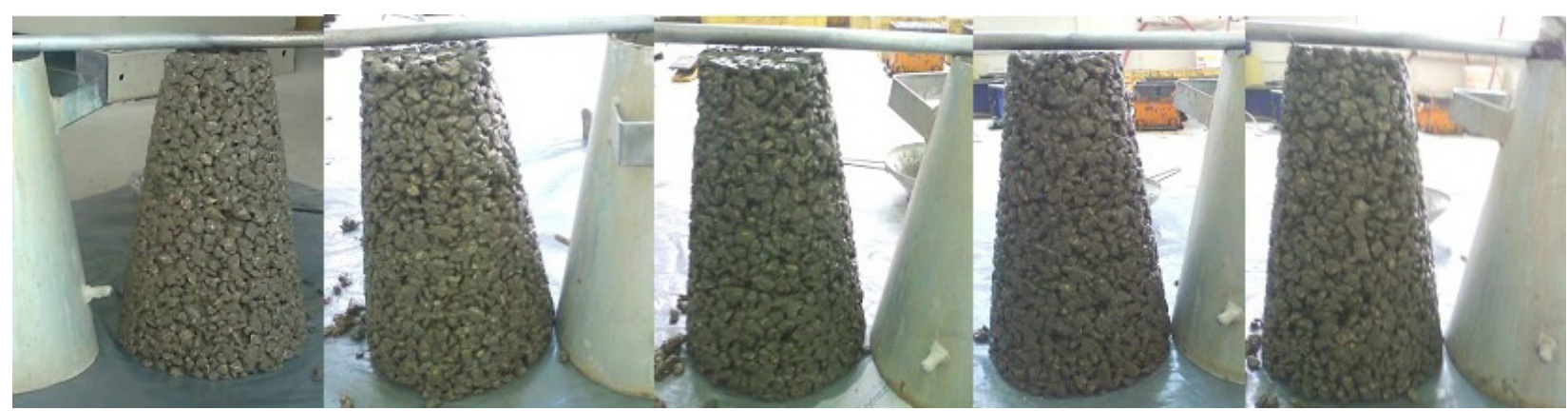

FIGURE 4. Slump test for reference mixture and mixtures with $\mathrm{G}, \mathrm{C}, \mathrm{PP}$ and $\mathrm{H}$ fibres.

moulds $24 \mathrm{~h}$ after casting and placed in water, while the specimens for permeability testing were put with a mould without base in the water $24 \mathrm{~h}$ after casting. The specimens were cured in water at $20 \pm 5^{\circ} \mathrm{C}$ until the test day, according to (38).

Porosity $(\mathrm{P})$ was tested on cube specimens and calculated by the expression (Equation [1]):

$$
P=1-\left(\frac{\frac{M_{1}-M_{2}}{\rho_{w}}}{V}\right) \cdot 100(\%)
$$

where $M_{1}$ is dry mass, $M_{2}$ is the pervious concrete specimen submerged underwater weight, $\rho_{w}$ is the density of water, and $\mathrm{V}$ is the specimen volume.

Density and compressive strength were tested in cube specimens according to (39) and (40), respectively. The density was tested on the same specimens as compressive strength, on the series of three cubes for each mixture, prior to compressive strength determination. Splitting tensile strength was tested in cylinder specimens according to (41). Splitting tensile strength was tested on two samples for each mixture.

Permeability was tested using the falling head method $(\mathrm{FH})$ and constant head method $(\mathrm{CH})$ in cylindrical specimens. The permeability was tested on the same specimens as splitting tensile strength and prior to splitting tensile strength determination.

Huang et al. (42) and Huang et al. (43) derived expression for pseudo coefficient of permeability, because of high porosity and the interconnected air voids path in pervious concrete, Darcy's law for laminar flow is no applicable. In this paper, in accordance with Sandoval et al. (44), permeability by falling head method ( $\mathrm{FH})$ and constant head $(\mathrm{CH})$ was tested on cylindrical specimens according to expressions (Equation [2]) and (Equation [3]). Permeability coefficient $\mathrm{FH}(\mathrm{mm} / \mathrm{s})$ was determined according to the expression (Equation [2]):

$$
F H=\frac{a}{A} \cdot \frac{L}{t} \cdot \log \frac{H_{1}}{H_{2}}
$$

where $\mathrm{a}$ is the area of the cylindrical pipe, $\mathrm{A}$ is the area of specimen, $\mathrm{L}$ is the length of specimen, $\mathrm{t}$ is the time required for the water to pass from level $\mathrm{H}_{1}$ to $\mathrm{H}_{2}$ through the pipe; $\mathrm{H}_{1}$ is initial height of water, $\mathrm{H}_{2}$ is final height of water. The permeability coefficient $\mathrm{CH}(\mathrm{mm} / \mathrm{s})$ was defined by the expression (Equation [3]):

$$
C H=\frac{V_{\mathrm{w}} \cdot L}{H_{0} \cdot A \cdot \Delta t}
$$

where $\mathrm{V}$ is the collected volume of water, $\mathrm{H}_{0}$ is constant for all tests and equal to $320 \mathrm{~mm}$, and $\Delta \mathrm{t}$ is $30 \mathrm{~s}$ in this test.

\section{RESULTS AND DISCUSSIONS}

Test results for the density, porosity, compressive and splitting tensile strengths, and permeability by both applied methods are shown in Table 2.

The effect of vibration on the porosity and permeability according to both methods used here was evaluated by the ratio of the properties of the vibrated mixtures and the mixtures of the same composition compacted with wooden lath and hammer (EV / E, GV / G, CV / C, PPV / PP, HV / H). Thus, the obtained relative values of porosity and permeability by both methods are given in Figure 5, while relative values of compressive and splitting tensile strengths are given in Figure 6.

The effect of incorporation of different types of fibres on the porosity and permeability according to both methods used here was evaluated by the ratio of the properties of the pervious concrete mixtures containing fibres and the reference pervious concrete mixtures, taking into consideration that in this case there are two reference mixtures: E mixture compacted with wooden lath and hammer and EV mixture compacted by short duration vibration. The following ratios of properties were considered in this way: G/E, C/E, PP/E, H/E, GV/EV, CV/EV, PPV/ $\mathrm{EV}$ and $\mathrm{HV} / \mathrm{EV}$. Thus, the obtained relative values of porosity and permeability by both methods are given 


\section{S. Juradin et al.}

TABLE 2. Test results for density, porosity, compressive strength, splitting tensile strength, and permeability by FH and CH methods with the standard deviation of each property.

\begin{tabular}{|c|c|c|c|c|c|c|c|c|c|c|}
\hline $\begin{array}{l}\text { Property/ } \\
\text { Concrete } \\
\text { mixture }\end{array}$ & $\mathrm{E}$ & EV & G & $\mathrm{GV}$ & $\mathrm{C}$ & $\mathrm{CV}$ & PP & PPV & $\mathrm{H}$ & $\mathrm{HV}$ \\
\hline Porosity (\%) & $33.6 \pm 2.7$ & $35.0 \pm 2.6$ & $31.1 \pm 1.8$ & $32.7 \pm 3.4$ & $32.6 \pm 1.8$ & $29.8 \pm 2.0$ & $35.1 \pm 2.1$ & $31.6 \pm 2.6$ & $35.8 \pm 2.1$ & $35.5 \pm 3.1$ \\
\hline Density $\left(\mathrm{kg} / \mathrm{m}^{3}\right)$ & $1850 \pm 11$ & $1755 \pm 51$ & $1900 \pm 50$ & $1890 \pm 18$ & $1950 \pm 32$ & $1850 \pm 11$ & $1898 \pm 14$ & $1900 \pm 42$ & $1780 \pm 80$ & $1820 \pm 11$ \\
\hline $\begin{array}{l}\text { Permeability } \\
\text { by falling head } \\
(\mathrm{FH}) \text { method } \\
(\mathrm{mm} / \mathrm{s}) \\
\end{array}$ & $22.77 \pm 2.41$ & $31.28 \pm 2.34$ & $19.04 \pm 1.47$ & $21.59 \pm 1.28$ & $16.67 \pm 1.04$ & $19.06 \pm 0.66$ & $20.70 \pm 1.00$ & $16.34 \pm 1.32$ & $20.12 \pm 1.15$ & $16.87 \pm 1.13$ \\
\hline $\begin{array}{l}\text { Permeability by } \\
\text { constant head } \\
(\mathrm{CH}) \text { method } \\
(\mathrm{mm} / \mathrm{s}) \\
\end{array}$ & $18.77 \pm 0.83$ & $25.27 \pm 1.01$ & $16.19 \pm 1.35$ & $18.50 \pm 1.10$ & $14.04 \pm 1.65$ & $15.91 \pm 0.47$ & $18.58 \pm 0.79$ & $13.99 \pm 0.50$ & $15.42 \pm 0.94$ & $14.24 \pm 0.80$ \\
\hline $\begin{array}{l}\text { Compressive } \\
\text { strength } \\
\left(\mathrm{N} / \mathrm{mm}^{2}\right) \\
\end{array}$ & $11.1 \pm 1.45$ & $8.3 \pm 0.87$ & $15.6 \pm 2.32$ & $16.8 \pm 0.92$ & $11.9 \pm 1.45$ & $18.6 \pm 0.45$ & $15.2 \pm 2.55$ & $17.6 \pm 0.67$ & $9.8 \pm 1.35$ & $11.3 \pm 0.56$ \\
\hline $\begin{array}{l}\text { Splitting tensile } \\
\text { strength } \\
\left(\mathrm{N} / \mathrm{mm}^{2}\right)\end{array}$ & $1.66 \pm 0.05$ & $1.32 \pm 0.11$ & $2.08 \pm 0.26$ & $2.14 \pm 0.28$ & $2.11 \pm 0.16$ & $1.84 \pm 0.12$ & $1.49 \pm 0.04$ & $1.65 \pm 0.06$ & $1.22 \pm 0.14$ & $1.94 \pm 0.14$ \\
\hline
\end{tabular}

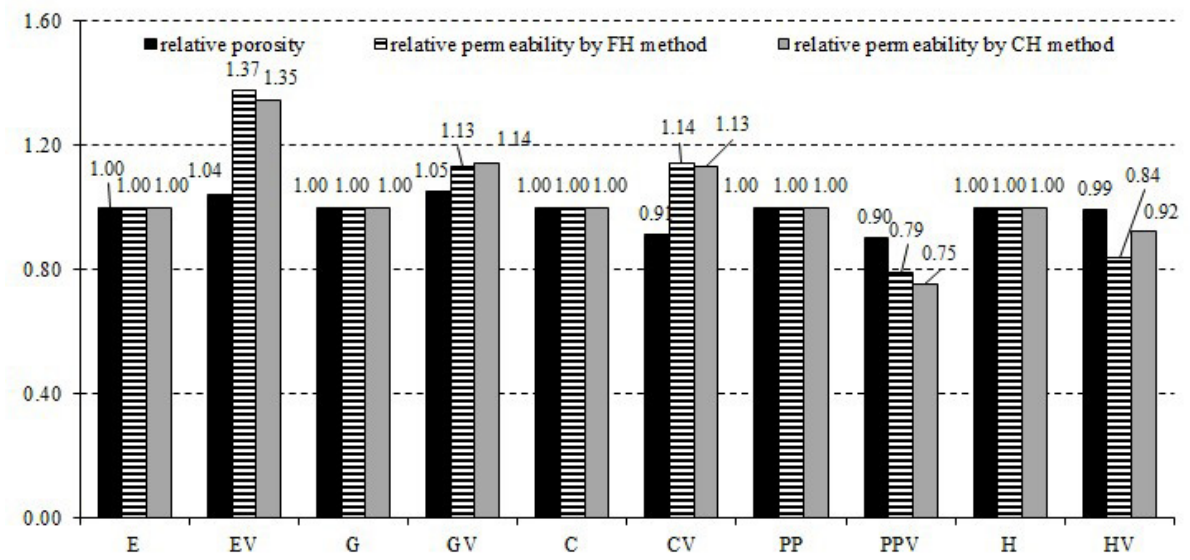

FIGURE 5. The effect of vibration on porosity and permeability of pervious concrete mixtures using $\mathrm{FH}$ and $\mathrm{CH}$ methods.

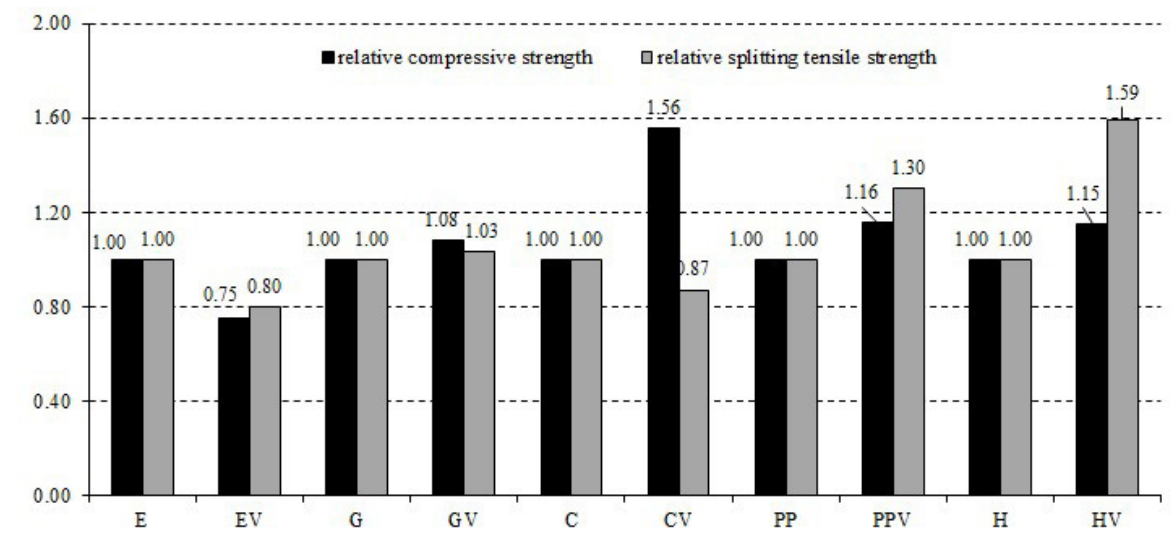

FIGURE 6. The effect of vibration on compressive and splitting tensile strengths of pervious concrete mixtures. 

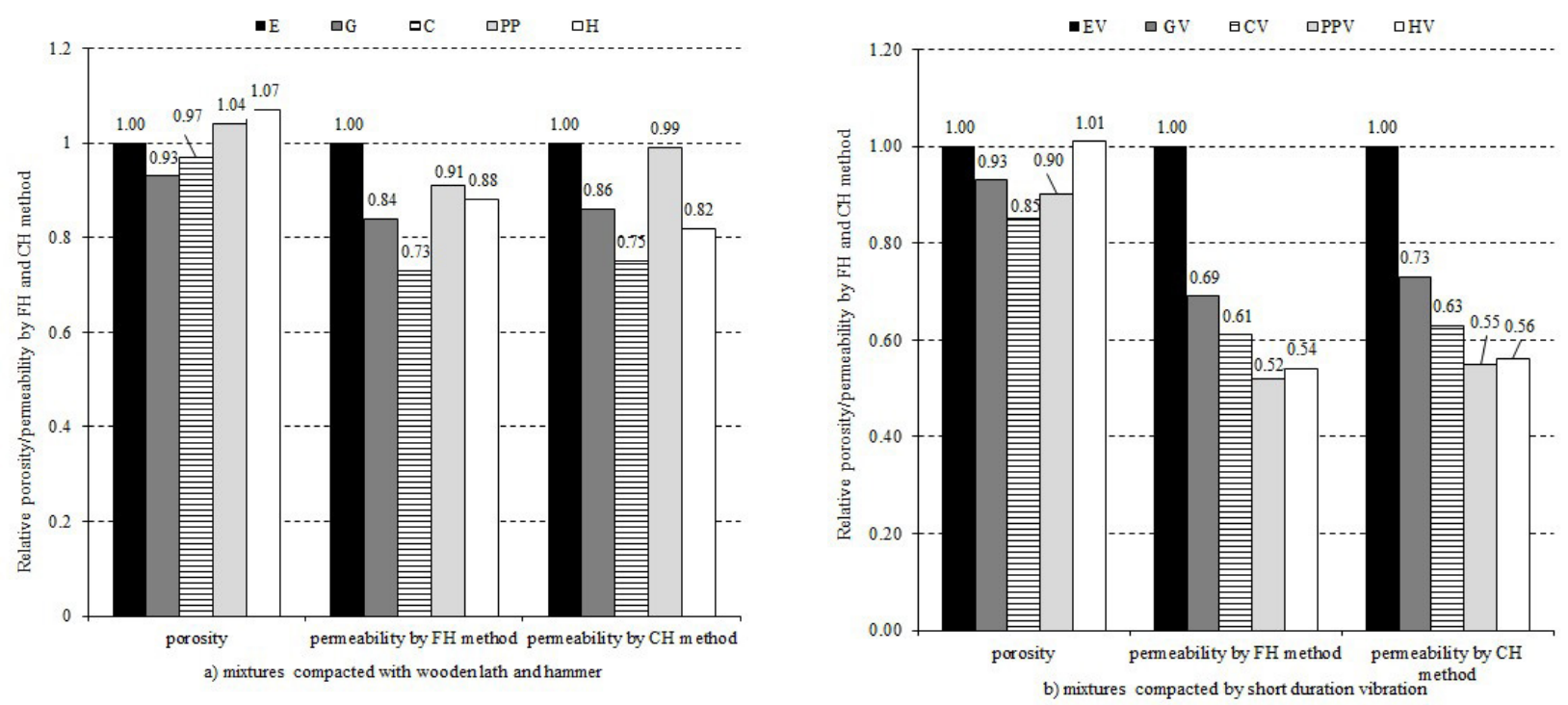

FIGURE 7. The effect of fibre incorporation on porosity and permeability of pervious concrete mixtures using $\mathrm{FH}$ and $\mathrm{CH}$ methods: a) mixtures compacted with wooden lath and hammer, b) mixtures compacted by short duration vibration.
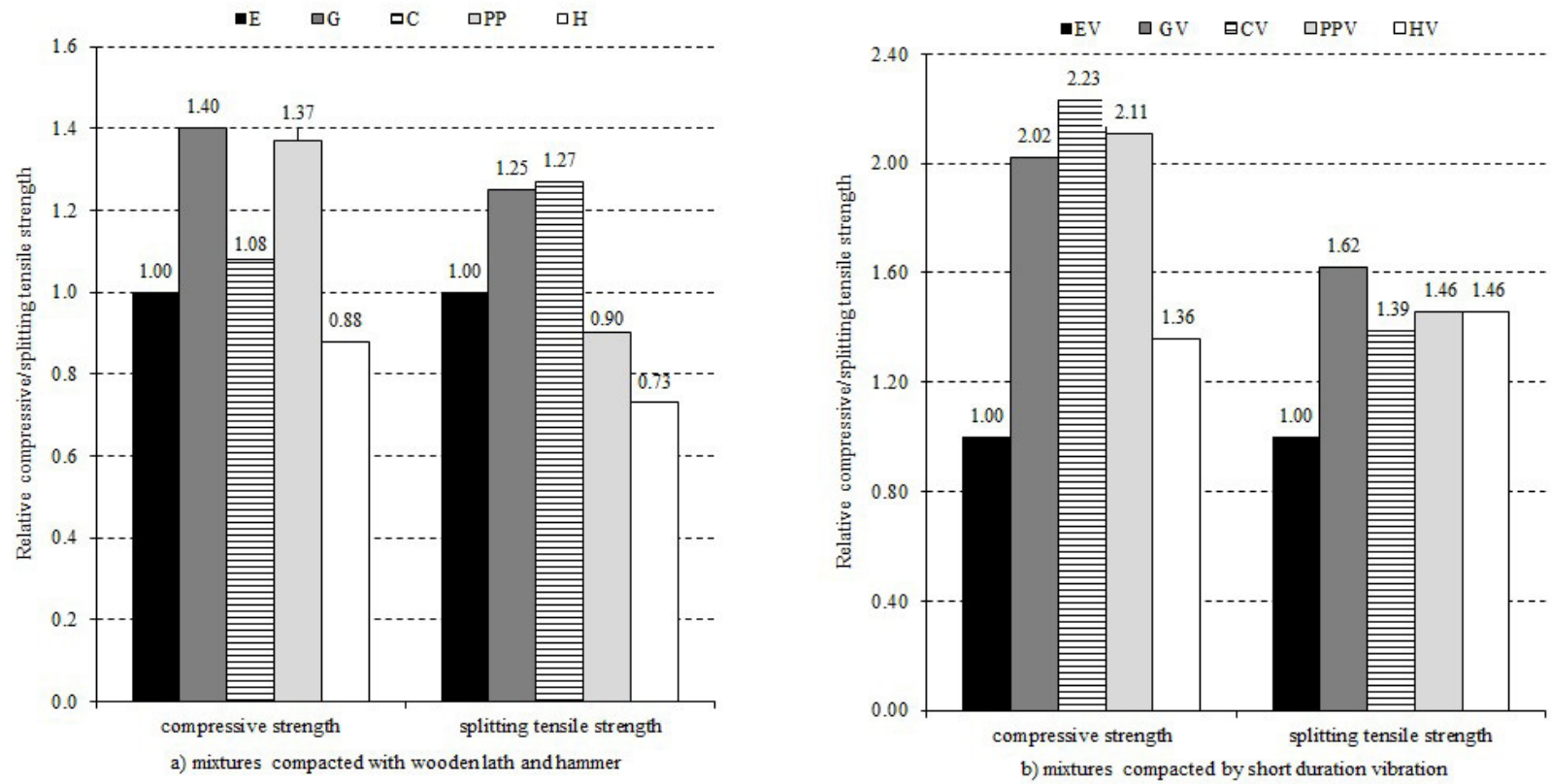

FIGURE 8 . The effect of fibre incorporation on compressive and splitting tensile strengths of pervious concrete mixtures: a) mixtures compacted with wooden lath and hammer, b) mixtures compacted by short duration vibration.

in Figure 7, while relative values of compressive and splitting tensile strengths are given in Figure 8.

The appearances of pervious concrete mixtures with incorporated carbon fibres, both vibrated (CV) and compacted with a wooden lath and hammer (C), are shown in Figure 9 and Figure 10.

The referent mixtures and the appearances of pervious concrete mixtures compacted with wooden lath and hammer or vibrated integrated with different types of fibres are shown in Figure 11.

From Table 2, it is clear that the density values range from 1755 to $1950 \mathrm{~kg} / \mathrm{m}^{3}$ and the porosity from 29.8 to $35.8 \%$, which is more than the usually achieved values of 15 to $25 \%$ for porosity of pervious concrete (5). This result for porosity is expected for single-sized aggregates and in accordance with 


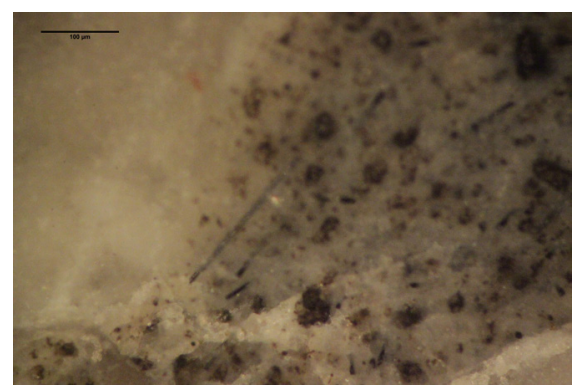

FIGURE 9. C mixture without viscous layer and the fibre-filled matrix (specimen $\mathrm{C}$ under the polarisation microscope BK-POLR).

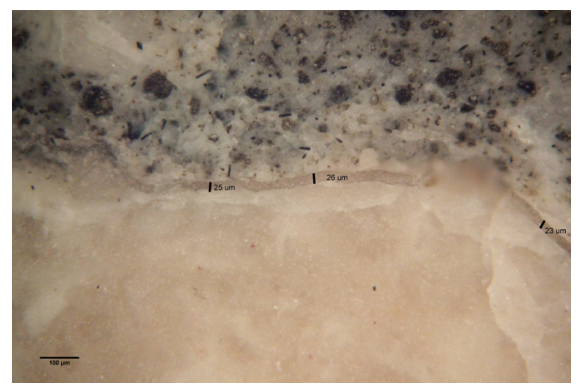

FIGURE 10. CV mixture with visible viscous layer and the fibre-filled matrix (specimen $\mathrm{CV}$ under the polarisation microscope BK-POLR).
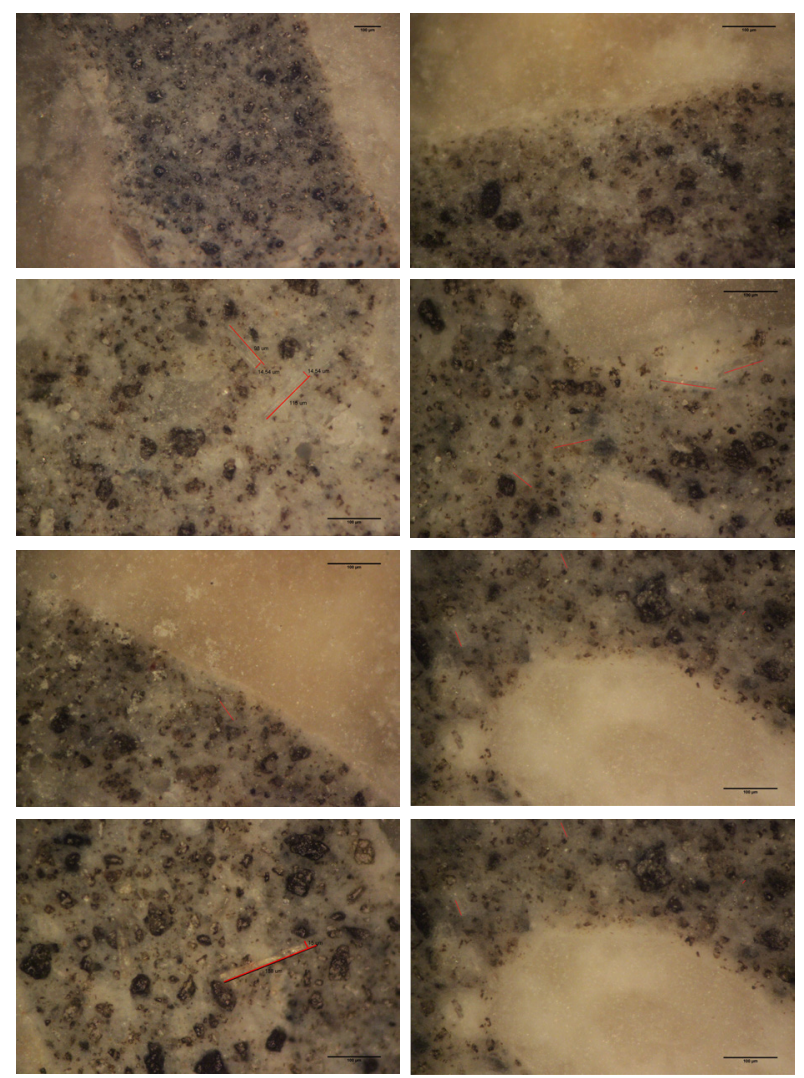

FIGURE 11. The appearance of pervious concrete mixtures compacted with wooden lath and hammer and mixtures compacted by short duration vibration under the polarisation microscope BK-POLR: a) E mixture (left) and EV mixture (right), b) G mixture (left) and GV mixture (right), c) P mixture (left) and PV mixture (right) and d) $\mathrm{H}$ mixture (left) and HV mixture (right). the results in previous research that have shown that a larger grain ensures good permeability of concrete (45-47). Figure 12 shows the specimens of pervious concrete after the splitting tensile test. According to the visible large pores, it is clear why concretes have such high porosity and good permeability.

The values of permeability obtained by the $\mathrm{FH}$ method are slightly higher than the values obtained by the $\mathrm{CH}$ method for all of the mixtures (Table 2). The highest value of permeability was achieved in the case of the concrete mixture EV $(31.28 \mathrm{~mm} / \mathrm{s}$ according to the $\mathrm{FH}$ method and $25.27 \mathrm{~mm} / \mathrm{s}$ according to the $\mathrm{CH}$ method), followed by E, GV, and PP. All values of permeability obtained herein are higher than $2-12 \mathrm{~mm} / \mathrm{s}$, the typical permeability value for pervious concrete $(2,5)$. A positive effect of vibration on the porosity and permeability according to the $\mathrm{FH}$ and $\mathrm{CH}$ methods (Figure 5) was observed for $\mathrm{EV}, \mathrm{GV}$, and $\mathrm{CV}$ mixtures, while it was absent for PPV and HV mixtures. Figure 12 shows a smaller proportion of pores in PPV concrete than in PP concrete which justifies such results.

From Table 2, it is clear that the compressive strengths of pervious concrete range from 8.3 to 18.6 $\mathrm{N} / \mathrm{mm}^{2}$ while the splitting tensile strengths range from 1.22 to $2.14 \mathrm{~N} / \mathrm{mm}^{2}$. Similar results were achieved in the research of Mahalingam and Mahalingam (48). In their study, the compressive strength and splitting tensile strength values varied from $5 \mathrm{MPa}$ to $16 \mathrm{MPa}$ and from 1.15 MPa to $1.7 \mathrm{MPa}$, respectively. A positive effect of vibration on the compressive and splitting tensile strengths (Figure 6) was observed for all the mixtures with fibres incorporated while it was absent for the reference concrete mixture, EV. The reason for the positive effect of vibration on the properties of pervious concrete may be found by comparing Figure 10 with Figure 11. Specifically, Figure 10 shows a viscous layer $23-26 \mu \mathrm{m}$ thick formed at the contact surface between the aggregate grain and the cement matrix in the vibrated mixture $\mathrm{CV}$ while there is no such layer in the mixture $C$ compacted with wooden lath and hammer (Figure 9). Formation of a viscous layer by vibration of concrete specimens was already confirmed in a study by Juradin and Krstulović (49). According to (21), vibration improves the quality of the interfacial zone between the cement paste and aggregates, which is usually the weakest link in terms of mechanical properties.

It can be seen from Figure 7 that, in this research, the fibres almost always adversely affect the porosity and, consequently, the permeability of pervious concrete. In contrast, Figure 8 shows the positive effect of fibres on the compressive and splitting tensile strengths of concrete. An exception here is $\mathrm{H}$ mixture which recorded a decrease in compressive and splitting tensile strengths (12\% for compressive strength and $27 \%$ for splitting tensile strength) compared with the reference mixture (E). There is a positive effect of fibres on mechanical properties of pervious concrete because the fibres 

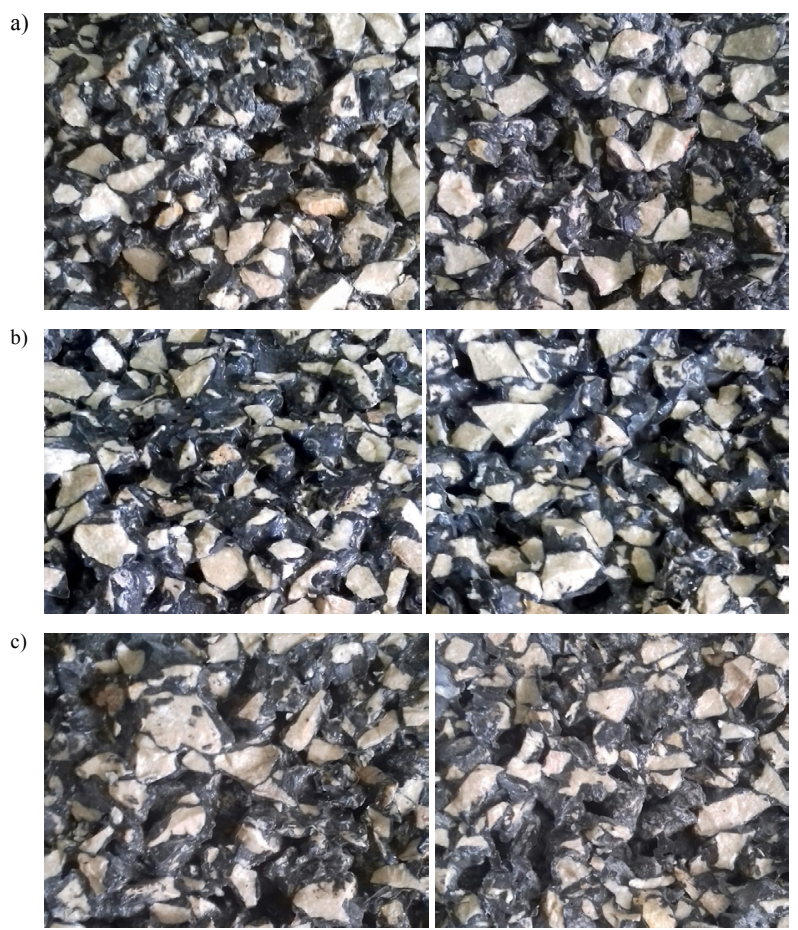

d)
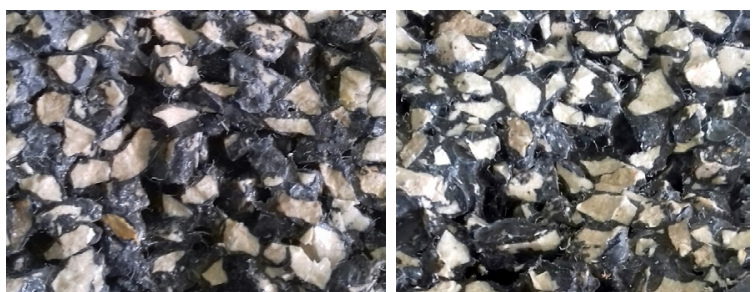

e)

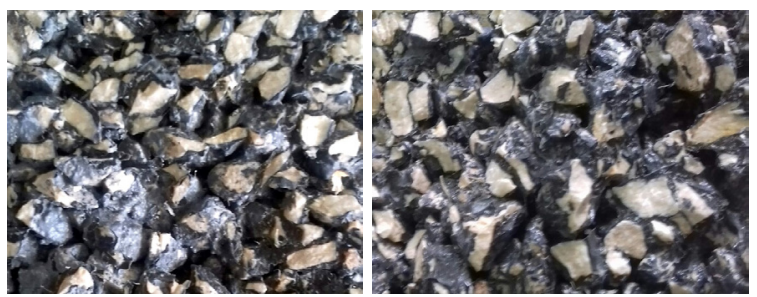

FIGURE 12. The appearance of pervious concrete specimens after splitting strength test: a) E mixture (left) and EV mixture (right), b) C mixture (left) and CV mixture (right), c) G mixture (left) and GV mixture (right), d) PP mixture (left) and PPV mixture (right) and e) $\mathrm{H}$ mixture (left) and $\mathrm{HV}$ mixture (right).

bridge the gap between the coarse aggregates and bind the pervious concrete mixture with the fibre-filled matrix $(11,50)$, and because fibre reinforcements may supress the generation and growth of cracks in the interface (51). Hesami et al. (29) incorporating glass, steel and polyphenylene sulphide (PPS) fibres and Geethanjali et al. (52) using polypropylene fibres obtained an improvement in strength in regards to the control mixtures. The authors in (52) concluded that the increase in strength is because of the polypropylene fibres in pervious concrete enhances the bonding between the coarse aggregate and cement paste. Rangelov et al. (6) used CCFCM elements (cured carbon fibre composite material) and improvements in mechanical properties have been observed on compressive and tensile strength. Infiltration rates were increased, especially on fibre reinforced slab specimens. Oni et al. (32) on specimens with Kevlar, PVA and UHMWPE fibres got an increase in the permeability but decrease in compressive and splitting tensile strength, when compared with the control group. Similar strength results but poorer permeability was obtained by Pils et al. (31) on specimens with PP fibres in regards to control mixture.

Of all the fibres studied herein, glass and carbon fibres improved the splitting tensile strength of pervious concrete mixtures the most. An explanation could be found in the number of fibres connecting the aggregate and the cement paste. Fibres are characterised by their aspect ratio, i.e. by the length to diameter ratio and aspect ratio for hemp and propylene differs significantly from the value for glass and carbon fibres, Table 1. Specifically, glass and carbon fibres have a smaller diameter than polypropylene and hemp fibres; thus, in the same volume of all fibres a higher number of fibres can be found in glass and carbon fibres than in propylene and hemp fibres (Figure 11). Furthermore, a higher number of fibres bridging the interfacial transition zone would imply better mechanical properties of pervious concrete.

The authors in (6) and (31) noticed the importance of compaction. In (31), in conclusion it stands: “... mechanical compaction should be used so that the mechanical properties are improved...". As can be seen in Figure 8, the positive effect of fibre addition was more emphasised in the case of vibrated mixtures - i.e., mechanical properties of vibrated mixtures with incorporated fibres $(\mathrm{HV}, \mathrm{GV}, \mathrm{CV}$, PPV) achieved higher relative values with respect to their reference mixture (EV) than mixtures compacted with wooden lath and hammer $(\mathrm{H}, \mathrm{G}, \mathrm{C}, \mathrm{PP})$ with respect to their reference mixture (E). After all, the value of the standard deviation for compressive strength is lower for vibrated specimens, Table 2 .

In future research, the authors of this paper will explore the possibility of using such concrete in paving concrete blocks and flags according to (53) and (54). Since very high permeability of concrete was obtained in this paper, the addition of a fine aggregate is expected to improve the mechanical properties of concrete, with a permeability that is in the acceptable range. Given the drainage capability of pervious concrete, such blocks and flags would certainly contribute to flood protection in urban areas.

\section{CONCLUSION}

Ten mixtures of pervious concrete were prepared, five of which were compacted by wooden lath and hammer and five by short duration vibration. Fibres of various origins were added to the mixtures: polypropylene, glass, carbon, and hemp fibres. Density, 
porosity, permeability (by $\mathrm{FH}$ and $\mathrm{CH}$ methods), compressive strength and splitting strength were tested in hardened pervious concrete specimens. An examination of the structure of concrete was made using a polarisation microscope. According to the results obtained, the following can be concluded:

- Compaction of pervious concrete with a short duration vibration of $5 \mathrm{~s}$ did not cause sedimentation of the cement paste, which would negatively affect permeability of concrete. Moreover, mixtures compacted by a short duration vibration achieved better pore-related properties (porosity and permeability) as well as mechanical properties due to the formation of a viscous layer at the contact surface between the aggregate grain and the cement matrix during compaction.

- The addition of fibres to the pervious concrete mixtures almost always adversely affected the porosity and, consequently, the permeability of pervious concrete, but had no effect on the density of concrete. In general, a positive effect of fibres on the compressive and splitting tensile strengths of concrete was recorded and this was even more emphasised in the case of vibrated mixtures.

- The synergistic effect of fibres and short duration vibration compaction have proven to be good solutions for enhancing usually low mechanical properties of pervious concrete.

\section{REFERENCES}

1. Putman, B.J.; Neptune, A.I. (2011) Comparison of test specimen preparation techniques for pervious concrete pavements. Constr. Build. Mater. 25 [8], 3480-3485. https://doi. org/10.1016/j.conbuildmat.2011.03.039.

2. Schaefer, V.R.; Wang, K.; Suleiman, M.T.; Kevern, J. (2006) Mix design development for pervious concrete in cold climates. Technical report, National Concrete Pavement Technology Center, Iowa, USA.

3. Sonebi, M.; Bassuoni, M.; Yahia, A. (2016) Pervious concrete: Mix design, properties and applications. RILEM Tech. Lett. 10, 109-115. https://doi.org/10.21809/rilemtechlett.2016.24.

4. Yang, Z.; Ma, W.; Shen, W.; Zhou, M. (2008) The aggregate gradation for the porous concrete pervious road base material. J. Wuhan Univ. Technol.-Mat. Sci. Edit. 23, 391-394. https://doi.org/10.1007/s11595-007-3391-4.

5. Tennis, P.D.; Leming, M.L.; Akers, D.J. (2004) Pervious concrete pavements, EB302.02, Portland Cement Association, Skokie, Illinois, and National Ready Mixed Concrete Association.

6. Rangelov, M.; Somayeh, N.; Haselbach, L.; Englund, K. (2016) Using carbon fiber composites for reinforcing pervious concrete. Constr. Build. Mater. 126, 875-885. https:// doi.org/10.1016/j.conbuildmat.2016.06.035.

7. Netinger Grubeša, I.; Barišić, I.; Ducman, V.; Korat, L. (2018) Draining capability of single-sized pervious concrete. Constr. Build. Mater. 169, 252-260. https://doi.org/10.1016/j. conbuildmat.2018.03.037.

8. Bentur, A.; Mindess, S. (2007) Fiber reinforced cementitious composites. Modern concrete technology series, CRC Press, Taylor \& Francis Group.

9. Mobasher, B. (2011) Mechanics of fiber and textile reinforced cement composites, CRC Press, Taylor \& Francis Group, Boca Rotan, London and New York.

10. Johnston, C.D. (2010) Fiber-reinforced cements and concretes, Taylor \& Francis, London and New York.

11. Amde, A.M.; Rogge, S. (2013) Development of high quality pervious concrete specifications for Maryland conditions. Final Report, MD-13-SP009B4F.

12. Kevern, J. T.; Biddle, D.; Cao, Q. (2014). Effects of macrosynthetic fibers on pervious concrete properties. J. Mater. Civil. Eng. 27 [9], 06014031-1-06014031-6. https://doi. org/10.1061/(ASCE)MT.1943-5533.0001213.

13. Kevern, J.; Schaefer, V.; Wang, K.; Suleiman, M. (2008) Pervious concrete mixture proportions for improved freeze-thaw durability. J. ASTM Int. 5 [2], 1-12. https://doi.org/10.1520/ JAI101320.

14. Kevern, J.T.; Wang, K.; Schaefer, V.R. (2008) Pervious concrete in severe exposures: Development of pollution-reducing pavement for northern cities. ACI Concr. Int. Mag. 43-49.

15. Rehder, B.; Banh, K.; Neithalath, N. (2014) Fracture behavior of pervious concretes: The effects of pore structure and fibers. Eng. Fract. Mech. 118, 1-16. https://doi.org/10.1016/j. engfracmech.2014.01.015.

16. Liu, R.; Chi, Y.; Jiang, Q.; Meng, X.; Wu, K.; Li, S. (20121 Physical and mechanical properties of pervious concrete with multi-admixtures. Mag. Concr. Res. 73 [9], 448-463. https:// doi.org/10.1680/jmacr.19.00145.

17. Shu, X.; Huang, B.; Wu, H.; Dong, Q.; Burdette, E.G. (2011) Performance comparison of laboratory and field produced pervious concrete mixtures. Constr. Build. Mater. 25 [8], 3187-3192. https://doi.org/10.1016/j.conbuildmat.2011.03.002.

18. Rizvi, R.; Tighe, S.L.; Henderson, V.; Norris, J. (2009) Laboratory sample preparation techniques for pervious concrete. Transportation Research Record Journal of the Transportation Research Board 09-1962:16 (2009).

19. Kevern, J.T.; Schaefer, V.R.; Wang, K. (2009). Evaluation of pervious concrete workability using gyratory compaction. $J$. Mater. Civil. Eng. 21 [12], 764-770. https://doi.org/10.1061/ (ASCE)0899-1561(2009)21:12(764).

20. Li, L.G.; Feng, J.J.; Zhu, J.; Chu, S.H.; Kwan, A.K.H. (2019) Pervious concrete: Effects of porosity on permeability and strength. Mag. Concr. Res. 73 [2], 69-79. https://doi. org/10.1680/jmacr.19.00194.

21. Zhuge, Y. (2008). Comparing the performance of recycled and quarry aggregate and their effect on the strength of permeable concrete. In Futures in Mechanics of Structures and Materials Toowoomba, Australia. 343-349.

22. Juradin, S.; Ostojić-Škomrlj, N.; Brnas, I.; Prolić, M. (2020) Influence of binder, aggregate and compaction techniques on the properties of single-sized pervious concrete. $A d v$. Concr. Constr. 10 [3], 211-220. https://doi.org/10.12989/ acc.2020.10.3.211.

23. Zhong, R.; Leng, Z.; Poon, C-S. (2018) Research and application of pervious concrete as a sustaninable pavement material: A state-of-the-art and state-of-the-practice review, Constr. Build. Mater. 183, 544-553. https://doi.org/10.1016/j. conbuildmat.2018.06.131.

24. Tabatabaeian, M.; Khaloo, A.; Khaloo, H. (2019) An innovative high performance pervious concrete with polyester and epoxy resins. Constr. Build. Mater. 228, 116820. https://doi. org/10.1016/j.conbuildmat.2019.116820.

25. Zhong, R.; Wille, K. (2015) Material Design and Characterization of High Performance Pervious Concrete. Constr. Build. Mater. 98, 51-60. https://doi.org/10.1016/j.conbuildmat.2015.08.027.

26. Tang, C.W.; Cheng, C-K.; Tsai, C-Y. (2019) Mix design and mechanical properties of high-performance pervious concrete. Mater. 12 [16], 2577. https://doi.org/10.3390/ ma12162577.

27. Kharbikar, F.V.; Pathak, S. (2017) Enhancing the strength of pervious concrete using polypropylene fiber, IJARIIE-ISSN(O)-2395-4396. 3 [4], 235-246.

28. Thakre, N.; Rajput, H.; Saxena, J.; Mitangale, H. (2014) Comparative Study on Strength and Permeability of Pervious Concrete by Using Nylon and Polypropylene Fiber, IJCAT Int. J. Comput. Technol. 1 [4], 141-148.

29. Hesami, S.; Ahmadi, S.; Nematzadeh, M. (2014) Effects of rice husk ash and fiber on mechanical properties of pervious concrete pavement. Constr. Build. Mater. 53, 680-691. https://doi.org/10.1016/j.conbuildmat.2013.11.070.

30. Patidar, R.; Yadav, S. (2017) Experimental Study Of Pervious Concrete With Polypropylene Fiber. Int. Res. J. Eng. Technol. (IRJET). 4 [12], 22-27. 
31. Pils, S.E.; Oliveira, P.; Regoso, F.; Paulon, V.A.; Costella, M.F. (2019) Pervious concrete: study of dosage and polypropylene fibers addiction. Rev. IBRACON Estrut. Mater. 12 [1], 101121. https://doi.org/10.1590/s1983-41952019000100009.

32. Oni, B.; Xia, J.; Liu, M. (2020) Mechanical properties of pressure moulded fibre reinforced pervious concrete pavement brick. Case Stud. Constr. Mater. 13, e00431. https://doi. org/10.1016/j.cscm.2020.e00431.

33. Zhong, R.; Wille, K. (2018) Influence of matrix and pore system characteristics on the durability of pervious concrete. Constr. Build. Mater. 162, 132-141. https://doi.org/10.1016/j. conbuildmat.2017.11.175.

34. AlShareedah, O.; Nassiri, S.; Dolan, D. (2019) Pervious concrete under flexural fatigue loading: Performance evaluation and model development. Constr. Build. Mater. 207, 17-27. https://doi.org/10.1016/j.conbuildmat.2019.02.111.

35. FORTA, Technical Report, FRP - Fiber Reinforced Pervious, 2013. http://www.tagroupkuwait.com/uploads/downloads/ pervious tech report.pdf.

36. Novak, J.; Kohoutkova, A.; Chylik, R.; Trtik, T. (2020) Study on pervious recycled aggregate fiber-reinforced concrete for airfield pavement, IOP Conf. Series: Materials Science and Engineering 770, 8th Global Conference on Materials Science and Engineering (CMSE2019). 12-15 November 2019, Sanya, China, (2020). https://iopscience.iop.org/article/10.1 088/1757-899X/770/1/012040/meta

37. (2019a) EN 12350-2:2019 Testing fresh concrete - slump test.

38. (2019b) EN 12390-2:2019 Testing hardened concrete - Part 2: Making and curing specimens for strength tests.

39. (2019c) EN 12390-7:2019 Testing hardened concrete - Part 7: Determination of density.

40. (2019d) EN 12390-3:2019 Testing hardened concrete - Part 3: Compressive strength of test.

41. (2009) EN 12390-6:2009 Testing hardened concrete - Part 6: Tensile splitting strength of test specimens.

42. Huang, B.; Mohammad, L.; Raghavendra, A.; Abadie, C. (1999) Fundamentals of Permeability in Asphalt Mixtures. $J$. Assoc. Asph. Pav. Technol. 68, 479-500.

43. Huang, B.; Wu, H.; Shu, X.; Burdette, E.G. (2010) Laboratory evaluation of permeability and strength of polymer-mo- dified pervious concrete. Constr. Build. Mater. 24 [5], 818823. https://doi.org/10.1016/j.conbuildmat.2009.10.025.

44. Sandoval, G.F.B.; Galobardes, I.; Teixeira, R.S.; Toralles, B.M. (2017) Comparison between the falling head and the constant head permeability tests to assess the permeability coefficient of sustainable Pervious Concretes. Case Stud. Constr. Mater. 7, 317-328. https://doi.org/10.1016/j. cscm.2017.09.001

45. Krstulović, P. (2000) Properties and technology of concrete. Faculty of Civil Engineering, University of Split, Institut IGH, Split (in Croatian).

46. Andrew, I.; Bradley, J.P. (2010) Effect of aggregate size and gradation on pervious concrete mixtures. ACI Mat.J. 107 [6], 625-631.

47. ACI (American Concrete Institute) (2010) (Reapproved 2011) ACI 522R-10: Report on pervious concrete. American Concrete Institute, Farmington Hills, MI, USA.

48. Mahalingam, R.; Mahalingam, S. V. (2016). Analysis of pervious concrete properties. Građevinar. 68 [6], 493-501. https://doi.org/10.14256/JCE.1434.2015.

49. Juradin, S.; Krstulovic, P. (2012) The vibration rheometer the effect of vibration on fresh concrete and similar materials. Mater. Werks. 43 [8], 733-742. https://doi.org/10.1002/ mawe.201200769.

50. Patil, P.S.; Sonar, I.P.; Shinde, S. (2017) No fine concrete. Int. J. Concr. Technol. 3 [2], 1-13.

51. Kim, H.H.; Kim, C.S.; Jeon, J.H.; Park, C.G. (2016) Effects on the physical and mechanical properties of porous concrete for plant growth of blast furnace slag, natural jute fiber, and styrene butadiene latex using a dry mixing manufacturing process. Mater. 9 [2], 84. https://doi.org/10.3390/ma9020084.

52. Geethanjali, S.; Manonmani, B.; Sowmya, P.; Suvetha, T.; Balakumar, V. (2020) Experimental study of pervious (no fine) concrete. Int. J. Sci. Eng. Res. 11 [3], 83-86. https:// www.ijser.org/researchpaper/Experimental-study-of-Pervious-No-Fine-Concrete.pdf.

53. EN 1338:2004 Concrete paving blocks -- Requirements and test methods. (2004a)

54. EN 1339:2004 Concrete paving flags -- Requirements and test methods. (2004b) 